Administrative Issues Journal: Connecting Education, Practice, and Research, Summer 2020, Vol. 10, No. 1:1-15. DOI: 10.5929/2020.10.1.1

\title{
PROTECT STUDENTS' EDUCATIONAL FUTURES THROUGH SOCIAL CAPITAL OPPORTUNITIES IN SPORT AND NON - SPORT EXTRACURRICULAR ACTIVITIES
}

\author{
Dr. Roxanne Long, Ph.D. \\ University of North Texas
}

\begin{abstract}
This study provides empirical support that extracurricular participation correlates positively and significantly to future education, both directly and indirectly. However, which type of extracurriculars are best for students in their pursuit of higher education, sport or non - sport activities? Rooted in Social Capital Theory, the present study focuses on which type of participation provides the best capacity to acquire social capital that correlates to gains in higher education. Structural equation modeling was used with a representative, longitudinal sample of 5,239 ninth through twelfth graders. Total effects reveal that mixed participation (at least one sport and one non - sport activity) correlate with the highest future levels of education. This study greatly aids educational administrators' decisions including extracurricular offerings, funding, and experiential context to improve life chances of students.
\end{abstract}

Keywords: Extracurricular Participation, Social Capital, Educational Attainment, Education Administration

Categorizations: Research, Quantitative, Education Administration

$T$ he mission of the American public education system may be debatable. Initially, public education was formed to enhance and sustain democracy through education of citizens to be informed voters (Meyer, Ramirez, \& Soysal, 1992). However, American public education recently has been viewed as an institution that prepares students for higher learning. Level of education elicits tremendous life impact with achievements in education determining earning potential, positive health outcomes, and social inclusion (Lin, 1999; Thorpe et al., 2013). However, as college enrollment numbers continue to climb, college dropout rates continue to climb as well (Mahatmya and Smith, 2017).

Logically, students' previous school experiences increase the understanding of future education level. Public schools are an incredibly pervasive social institution within American society. Parents, teachers, coaches, sponsors, and school administrators are part of the matrix of decision-making in the public school structure. At the heart of this decision -making is the desire to improve the life chances of students. This study evaluates the experience of high schoolextracurricular activities in this regard.

School budgets have recently been under strain leading to the introduction of pay to participate programs (Barron et al., 2000; Bowen and Hitt, 2016; Snellman et al., 2015). The potential lack of access to activities through such programs is an urgent social concern since participation has implications for adult success (Pruter, 2013; Snellman et. al, 2015). The current study adds to the quality of knowledge 
PROTECT STUDENTS' EDUCATIONAL FUTURES THROUGH SOCIAL CAPITAL OPPORTUNITIES IN SPORTS AND NON-SPORT EXTRACURRICULAR ACTIVITIES

about extracurricular activities influence on students' futures helping guide various decisions, programs, policies, and budget allocation. Access to extracurricular activities may explain the growing achievement gap and therefore could be critical to the civic future of society (Bowen and Hitt, 2016; Snellman et. al., 2015). The research questions addressed: Which type of extracurricular activities correlate with students' future education, sport or non-sport? Is social capital an explanatory mechanism between high school participation and future education?

\section{Theoretical Framework}

Social Capital theory forms the theoretical framework for this study. Social capital is defined as a resource assembled through relationships within social structures (Coleman, 1988). Youth social capital specifically includes social networks, trust and reciprocity, and sense of belonging (Schaefer-McDaniel, 2004). The full model used for this study places social capital as the mechanism explaining student's extracurricular participation's impact on future education level. Adolescents spend much of their time in the school environment, and therefore school-related factors are a significant part of youth social capital (Nielsen et al., 2015; Strohschein and Matthew, 2015; Weiss, 2012;). Social capital in this light can be defined as investments between students and schools (Dufur et al., 2013). Those investments can translate into educational outcomes. Therefore, school environments can either empower or alienate youth (StatonSalazar, 2011). As Morrow (2004) suggests, the school is, in essence, a youth's neighborhood.

Relationships at school become increasingly important as children grow into adolescence (Dufur et al., 2013; Parcel et al., 2010; Strohschein and Matthew, 2015; Weiss, 2012). School officials, as institutional agents, become a non-familial adult offering exposure to additional social capital (StatonSalazar, 2011). Schools, through socialization, also create an accumulative social capital (Arriaza, 2003). For example, schools become one of the dominant conduits of teaching norms and beliefs (Paccagnella and Sestito, 2014; Stanton-Salazar, 2011). School related factors that contribute to accumulative social capital formation include the general academic atmosphere, safety, and tolerance (Weiss, 2012).

Alternatively, a lack of these factors may create schools that deny social capital and perpetuate inequalities (Arriaza, 2003). Social capital is not always beneficial as social capital could breed exclusion (Strohschein and Matthew, 2015).

Social capital in schools opens vertical relationships as well (Staton-Salazar, 2011). Vertical relationships are those relationships between individuals of multiple power levels, many times termed linking social capital (Allan and Catts, 2014). Linking capital can be especially powerful in its ability to affect outcomes such as educational attainment (Allan and Catts, 2014; Staton-Salazar, 2011; Woolcock, 1998). Teaching students how to navigate education-based institutional forces is one way that linking social capital leads to positive outcomes (Arriaza, 2003). Adults in schools hold experiential knowledge of educational attainment which extends to specific and practical information (Broh, 2002; Dufur et al., 2013; Stanton-Salazar, 2011). Also, institutional agents in schools transmit resources explicitly connected to educational attainment, such as recommended high school courses or the college application process (StatonSalazar, 2011). Therefore, school officials may be capable of "counter stratification", connecting those without traditional ties to higher education to meaningful resources through purposeful social capital interaction (Stanton-Salazar, 2011). School sponsored extracurricular activities logically allow more access and opportunity for such relationships (Allan and Catts, 2014; Dufur et al., 2013; Haff et al., 2010; StantonSalazar, 2011). Therefore, activities beyond the home and regular school day are principally important for the study of youth social capital (Rothon, Gooodwin, \& Stansfield, 2012). More sociological theory needs incorporation into the research of outcomes of 
PROTECT STUDENTS' EDUCATIONAL FUTURES THROUGH SOCIAL CAPITAL OPPORTUNITIES IN SPORTS AND NON-SPORT EXTRACURRICULAR ACTIVITIES

extracurricular activities since sociological theory provides insight into the differing outcomes of participation (Broh, 2002).

\section{Literature Review}

Extracurricular participation is not uniform; not all students participate in sports. Previous literature has typically addressed participation as a whole or evaluated only the category of sports. Today, sports are the most popular school-sponsored activity in the United States (Eide and Ronan, 2001) with over half of high school students involved in a school-sponsored sport (Koebler, 2011). The popularity and general structure of sport involves large numbers of people (Widdop et al., 2016) which logically provides a greater chance of expanding social networks.

Studies that address sports only include Barron et al. (2000) who explored sports' influence on future educational attainment finding a positive correlation. Mechanisms of productivity and industriousness explained sports' unique ability to enhance skills necessary for educational success (Barron et al., 2000). Shifrer et. al (2015) also focused on sports finding a positive correlation to college enrollment; yet, the study did not assess attainment. Gorry (2016) compared individual and team sports' effect on high school grades and high school completion with positive results with team sports showing a stronger correlation. The positive effects from these previous studies do not include a comparison to other types of activities. And "it is imperative to test participation in different types of activities simultaneously to isolate the effects of participation in specific activities." (Broh, 2002, p.84).

Of those limited studies that compare sport and non-sport activities, sport participation had a stronger effect than non-sport on risk of dropping out of school (McNeal, 1995) and trust levels (Brown et al., 2014). More specifically, McNeal (1995) compared sports, fine arts, academic, and vocational clubs resulting in sports as the only type of participation that significantly reduced the risk of dropping out. Brown et al. (2014) found that community sports were a stronger predictor of trust levels as compared to other community organizations. However, this study was operationalized at the community level rather than the school level. Two studies found positive effects for both sport and music categories. Broh (2002) used a multicategorical approach resulting in only sport and music correlating to higher grades and standardized test scores. Similarly, Cabane et. al (2016) found only sport and music positively influenced grades and attendance at the university level. In contrast, Hanks and Eckland (1976) evaluated sport versus non-sport and found sports had little relevance to academic attainment while non-sport participation was a positive association.

Therefore, limited studies evaluate high school extracurricular participation's link with future educational attainment, with most addressing other academic outcomes or more short-term attainment. A further gap in previous research is the lack of testing the differing outcomes of sport versus non-sport extracurriculars. The sparse and varied approaches possibly explain the contradictory results. The current study adds to the limited research by separating types of extracurriculars while using the outcome variable of educational attainment. Previous studies identified above demonstrate methodological strength in representative, longitudinal samples, and duly controls considered; yet, two main components are missing from the conversation: 1) The most recent applicable nationally representative longitudinal data is used in this study gauging possible changes over the last decade. As a brief example, Hanks and Eckland (1976) provide similar variables in attainment and sport versus nonsport evaluation; however, data used was prior to the variety of extracurricular offerings and prior to the entrance of girls into interscholastic sports. 2) A mixed category (participation in at least one sport and one non-sport) is included to further isolate effects of participation type. No previous literature has 
PROTECT STUDENTS' EDUCATIONAL FUTURES THROUGH SOCIAL CAPITAL OPPORTUNITIES IN SPORTS AND NON-SPORT EXTRACURRICULAR ACTIVITIES

been identified that includes this categorization. Tight school schedules lend to students specializing in one type of activity making a mixed category especially informative.

\section{Method \\ Sample}

Data were drawn from the National Longitudinal Study of Adolescent to Adult Health (Add Health), a longitudinal, school-based, nationally representative study of American adolescents in grades 7 through 12 (Harris et al. 2009). Add Health gathered data through 5 waves from 1996-2016. The data was collected from 80 high schools and 52 middle schools and was stratified by region, urbanity, school type, ethnic mix, and size (Harris et al. 2009). Stratified by grade, sex, and race, Add Health samples 200 randomly selected students per school (Harris et al. 2009). Add Health gathered data from students, parents, and school administrators through five waves from 1994-2016. At Wave I, Add Health questioned a sample of 20,745 students, grades 7th-12th (Harris et al. 2009). The sample was restricted to 9th-12th grade students in Wave I, reducing the sample to 14,752. Focusing on high school activities that require more time and motivation strengthens the analysis (Cabane et al., 2016). A sample of 10,562 adolescents remained after excluding those cases missing a sampling weight. Lastly, list-wise deletion eliminated cases with missing study variables, leaving a final sample of 5,239.

\section{Measures}

Educational attainment was measured in Wave IV with students aged 25-34. Responses were recoded as: 1=eighth grade or less, $2=$ more than eighth, less than high school, 3=high school degree, 4=trade or vocational school, $5=$ some college, $6=$ college bachelor's degree, $7=$ =post-bachelor's education. All other variables were measured in Wave I. Comparison groups of extracurricular participation were recoded to identify four categories: sport, non-sport, mixed (both sport and non-sport), and none. Sport was coded as the reference group. The social capital construct operationalized through the adolescents themselves with more than one indicator, contributing a strong social capital construct to the literature (Dufur et al., 2013; Morrow, 1999; Morrow, 2001; Schaefer-McDaniel, 2004; Rothon, Goodwin, \& Stansfield, 2012; Strohschein and Matthew, 2015). Social capital was operationalized through both family and school. Family social capital used three student rated scale items from 1 (not at all) to 5 (very much) to the extent their family pays attention, understands, and has fun (Haff et al., 2010; Dufur et al., 2015; and Weiss, 2012). Cronbach's alpha score calculated .778. School social capital used five rated scale items from 1 (strongly agree) to 5 (strongly disagree) to the extent the student felt close to people at school, felt a part of the school, felt happy to be at school, felt students were treated fairly, and felt safe in school. Higher values indicated more school social capital by reverse coding. Cronbach's alpha score calculated a strong .783. The full model included social capital working through parent expectations and grade point average. Parent expectations contained one proxy item of disappointment (Mahatmya and Smith, 2017). Students rated from 1 (low) to 5 (high) the disappointment level of their parent(s) if they failed to graduate from college. Two parent household responses were summed and averaged to adjust for students with single parents or missing responses (Adedokun and Balschweid, 2008). The average of self-reported grades in english, history, science and mathematics calculated grade point average (Adedokun and Balschweid, 2008). Each student indicated his or her letter grade in these four subjects. Grades were reverse coded reflecting a typical grading scale $(A=4, B=3, C=2$, and $D$ or below=1). Cronbach's alpha score calculated a strong .712.

Demographic control variables incorporated in the analysis included gender $(0=$ female; $1=$ male), race ( $0=$ white; $1=$ black, non-white), and parent education level (resident parent(s) highest education level attained ranging from 1=eighth grade or less to $7=$ post bachelor's education). 
PROTECT STUDENTS' EDUCATIONAL FUTURES THROUGH SOCIAL CAPITAL OPPORTUNITIES IN SPORTS AND NON-SPORT EXTRACURRICULAR ACTIVITIES

\section{Analysis Strategy}

Structural Equation Modeling (SEM) was used to examine all paths, direct and indirect. SEM analyzes a matrix of associations between both latent and observed variables simultaneously (Hoyle \& Panter, 1995; Thompson, 2000). SEM estimates multiple, interdependent relationships; represents unobserved concepts with corrected measurement errors; and explains the entire set of relationships in one model (Hair \& Black, 2012). Therefore, SEM is distinct from factor analysis and linear regression (Hair \& Black, 2012). Important to the analysis of the current study, social capital can be evaluated completely through the variables of expectations and grade point average. Analysis was conducted using R software. SPSS constructed variables prior to model analysis. R completed all structural stages of analysis including stratified and clustered data using Lavaan, Survey, and Survey Design libraries. Lavaan estimated the SEM model while the survey and survey design libraries incorporated the cluster, weight, and strata variables.

\section{Results}

Table 1 depicts descriptive statistics for sample demographics. Almost 80 percent of students participated in extracurricular activities, with the majority participating in a mixture of sport and nonsport. The sample also showed relatively high educational attainment with 38 percent earning a bachelor's degree or higher. Female students are slightly more represented and the majority of the respondents identified as white.

\begin{tabular}{|c|c|c|c|}
\hline Variable & Percent & Variable & Percent \\
\hline Participation & & Parent Education & \\
\hline Sport & 21 & Less than HS & 10 \\
\hline Non-sport & 26 & HS Grad or GED & 27 \\
\hline Mixed & 33 & Some College/Vocational & 23 \\
\hline \multirow[t]{2}{*}{ None } & 20 & Bachelor Degree & 25 \\
\hline & & Beyond Bachelor & 15 \\
\hline \multicolumn{4}{|l|}{ Gender } \\
\hline & & Education Level & \\
\hline Female & 53 & Less than HS & 4 \\
\hline \multirow[t]{3}{*}{ Male } & 47 & HS Grad or GED & 14 \\
\hline & & Some College/Vocational & 44 \\
\hline & & Bachelor Degree & 23 \\
\hline Race & & Beyond Bachelor & 15 \\
\hline White & 57 & & \\
\hline Black & 18 & & \\
\hline Other & 25 & & \\
\hline
\end{tabular}

Table 1 Descriptive statistics for variables in the analysis.

Table 2 presents unstandardized parameter estimates for the full structural model including direct effects (B), indirect effects (Bie), total effects (BT), and coefficients of determination ( $R 2 s)$. Unstandardized estimates interpret the multi-category variable of participation. Model fit statistics indicated a good model fit. The Satorra-Bentler's corrected robust statistics remedy the violation of 
PROTECT STUDENTS' EDUCATIONAL FUTURES THROUGH SOCIAL CAPITAL OPPORTUNITIES IN SPORTS AND NON-SPORT EXTRACURRICULAR ACTIVITIES

distributional assumptions. The chi-square value was excluded as recommended for MLR estimation and sample size over one thousand (Kline, 2016).

\begin{tabular}{|c|c|c|c|c|}
\hline & Social Capital & $\begin{array}{l}\text { Parent } \\
\text { Expectations }\end{array}$ & GPA & $\begin{array}{l}\text { Educational } \\
\text { Attainment }\end{array}$ \\
\hline \multicolumn{5}{|c|}{ Direct Effects (B) } \\
\hline \multicolumn{5}{|c|}{ Participation } \\
\hline Mixed & $0.17^{*}$ & $0.20^{* * *}$ & $0.31^{* *}$ & $0.13^{*}$ \\
\hline Non-Sport & -0.07 & 0.11 & $0.31 * *$ & $0.12+$ \\
\hline None & $-0.64 * *$ & -0.08 & -0.01 & $-0.40 * *$ \\
\hline Social Capital & & $0.14^{* *}$ & $0.15^{* *}$ & 0.05 \\
\hline \multicolumn{5}{|c|}{ Indirect Effects $\left(B_{i e}\right)$} \\
\hline \multicolumn{5}{|c|}{ Participation } \\
\hline Mixed & & $0.02+$ & $0.04^{* *}$ & $0.23^{* *}$ \\
\hline Non-Sport & & -0.01 & -0.01 & $0.18^{* *}$ \\
\hline None & & $-0.09 * *$ & $-0.11^{* *}$ & $-0.11 * *$ \\
\hline \multicolumn{5}{|c|}{$\begin{array}{l}\text { Total Effects }\left(\mathrm{B}_{T}\right) \\
\text { Participation }\end{array}$} \\
\hline Mixed & & $0.23 * *$ & $0.35 * *$ & $0.36^{* *}$ \\
\hline Non-Sport & & 0.10 & $0.31^{* *}$ & $0.30 * *$ \\
\hline None & & $-0.17 *$ & $-0.12^{*}$ & -0.50 ** \\
\hline$R^{2}$ & 0.08 & 0.03 & 0.13 & 0.27 \\
\hline
\end{tabular}

Table 2 Structural Equation Model Unstandardized Parameter Estimates (Standard Error); Direct, Indirect, Total Effects and $R^{2} s(N=5,239$ Listwise)

Model Fit Indices: $x^{2}(100)=260.044, \mathrm{p}<0.001 ; \mathrm{CFI}=0.941$; SRMR $=0.041 ; \mathrm{RMSEA}=0.019$; RMSEA $90 \%$ confidence level $=.017$ to. 020

Note. $+0.10 \leq \rho<0.05 ; * 0.05 \leq \rho<0.01 ; * * \rho \leq 0.01$ (Two - Tailed Tests)

\section{Analysis}

Somewhat contrary to expectations, social capital did not have a significant, direct correlation with educational attainment, yet does have a significant, positive indirect and total correlation working through parent expectations and grade point average. Results clearly show participation is important to educational outcomes as those students that did not participate were significantly less likely to garner social capital and higher levels of education, both directly and indirectly through social capital.

Upon examination of total effects, differing types of participation yield interesting distinctions. Sport participation did show to have a more positive correlation on social capital than non-sport participation, although the result was not significant. Students involved in non-sport activities and mixed participation significantly correlate with higher levels of education than sport participants. The most important finding was in the mixed participation category. 
PROTECT STUDENTS' EDUCATIONAL FUTURES THROUGH SOCIAL CAPITAL OPPORTUNITIES IN SPORTS AND NON-SPORT EXTRACURRICULAR ACTIVITIES

Mixed participation demonstrated significantly higher levels of correlation to all measures including social capital and levels of education, directly and indirectly.

Results show methodological strength in representative sample provided by the complex design of Add Health as well as assessing a matrix of associations through structural equation modeling. Most importantly, Add Health data stratifies at the school level and individual student level. Therefore, data drawn incorporates varying levels of school wealth and allows for the important included controls of parent education level, race, and gender. Structural equation modeling permits analysis of associations within all variables (i.e. social capital, grade point average, and parent expectations) beyond extracurricular participation and education level attained.

\section{Discussion}

Rooted in social capital theory, extracurricular participation's correlation to higher education attainment was estimated. Consistent with previous research, extracurricular activities increased the opportunity to build social capital (Broh, 2002; Dufur et al., 2013; Haff et al., 2010; Stanton-Salazar, 2011). Interestingly, social capital significantly correlated with education level indirectly, rather than directly, through parent expectations and grade point average. Social capital only translates to educational attainment if resources garnered are capable, specific, and purposeful (Stanton-Salazar, 2011). Perhaps, social capital's path through parent expectations and grade point average renders resources specific and purposeful. Knowledge of this capital mobilization empowers institutional agents, such as schools, to best support students. Alternatively, social capital measured holistically may limit the study. Social capital measured more specifically in the contexts of extracurricular activity and higher education is a possible direction of future study. Social capital as the outcome variable, with no regard to level of education could also reveal more in-depth insight for school administrators.

In contrast to most previous studies that offered comparison of sport and non-sport activities (Broh, 2002; Brown et. al, 2014; Cabane et. al, 2016; McNeal, 1995), the present study found non-sport more strongly correlated with educational attainment. Total effects revealed that non-sport and mixture categories both significantly correlated to higher levels of education. Although, sports were slightly stronger in relationship to social capital. Perhaps students involved in both types of activities benefit from the various advantages of sport's influence on social capital while also reaping the found advantages of non-sport participation, namely grade point average.

The Add Health data constitutes limitations. For example, xchool extracurriculars and other extracurriculars combine in one survey item. One may speculate that the design of the survey naturally steers towards school sports and activities, but it is not a certainty. This distinction would enhance the study as previous research found school sports positively impacting academics while club sports showed negative effects (Broh, 2002). Secondly, level of participation such as varsity, junior varsity, or leadership status was not included in the survey. Level of participation could add compelling richness. Add Health also consists of self-reported survey items, a necessary mention in limitation. From an operational standpoint, extracurricular participation could be disaggregated further into a multitude of categories such as fine arts, musical arts, school service, academic clubs, team sports, individual sports, etc. Evaluating such distinct type of participation on outcomes would add tremendous depth to the knowledge of the field and administrator budget priority. 
PROTECT STUDENTS' EDUCATIONAL FUTURES THROUGH SOCIAL CAPITAL OPPORTUNITIES IN SPORTS AND NON-SPORT EXTRACURRICULAR ACTIVITIES

\section{Conclusion}

In conclusion, non-sport extracurricular participation is better correlated than sports to educational attainment. However, participation in both sports and non-sports (mixed) show the strongest correlation. Therefore, educational administrators should make extracurricular activities a priority at no charge as well as encourage participation in both types. Further study into the mixed category could also aid administrators in practice. For example, administrators could implement school schedules more conducive to student participation in multiple activities. Or perhaps schools are unintentionally encouraging sport or non-sport based on race, gender, or socioeconomic status. For instance, the sports scholarship culture carries a belief that sports are the absolute best path to achieving future education (Johnson and Migliaccio, 2009), even though only about $2 \%$ of high school athletes earn a college sports scholarship (O'Shaughnessy, 2012). Do students in the mixed category not subscribe to the sport scholarship culture? Or perhaps students that participate in both types of activities are already strongly college-bound and purposely building a varied admissions portfolio. Insight to these possibilities could greatly assist schools in educational direction.

\section{Acknowledgements}

Add Health was designed by J. Richard Udry, Peter S. Bearman, and Kathleen Mullan Harris and funded by grant P01-HD31921 from the Eunice Kennedy Shriver National Institute of Child Health and Human Development, with cooperative funding from 17 other agencies. Special acknowledgment is due Ronald R. Rindfuss and Barbara Entwisle for assistance in the original design. Persons interested in obtaining Data Files from Add Health, The University of North Carolina at Chapel Hill, Carolina population Center, 206 W. Franklin Street, Chapel Hill, NC 27516-2524 (addnealth.contracts@unc.edu). No direct support was received from grant P01-HD31921 for the current analysis. 
PROTECT STUDENTS' EDUCATIONAL FUTURES THROUGH SOCIAL CAPITAL OPPORTUNITIES IN SPORTS AND NON-SPORT EXTRACURRICULAR ACTIVITIES

\section{References}

Adedokun, O.A., \& Balschweid, M.A. (2008). The Mediating effects of self-esteem and delinquency on the relationship between family social capital and adolescents' educational achievement. Educate Journal 8 (1), 2-14. http://www.educatejournal.org/index.php/educate/article/view/153

Allan, J., \& Catts, R. (2014). Schools, social capital and space. Cambridge Journal of Education, 44(2), 217-228. doi: 10.1080/0305764X.2013.863829

Arriaza, G. (2003). Schools, social capital and children of color. Race Ethnicity and Education, 6(1), 71-94. doi: $10.1080 / 1361332032000044594$

Ashtiani, M. \& Feliciano, C. (2015). Access and Mobilization: How Social capital Relates to Low-Income Youth's Postsecondary Educational (PSE) Attainment. Youth \& Society, 123. https://doi.org/10.1177/0044118X15607163

Barron, J. M., Ewing, B. T., \& Waddell, G. R. (2000). The effects of high school athletic participation on education and labor market outcomes. The Review of Economics and Statistics, 82(3), 409-421. doi: 10.1162/003465300558902

Bowen, D. H., \& Hitt, C. (2016). History and evidence show school sports help students win. SAGE Publications.

Broh, B.A. (2002) Linking Extracurricular Programming to Academic Achievement: Who Benefits and Why? Sociology of Education, 75(1), 69-91. doi: 10.2307/3090254

Brown, K.M., Hoye, R., \& Nicholson, M. (2014). Generating trust? Sport and Community Participation. Journal of Sociology, 50(4), 437-457. doi: 10.1177/1440783312467091

Cabane, C., Hille, A. \& Michael Lechner (2016). Mozart or Pele? The effects of adolescents' participation in music and sports. Labour Economics 41, 90-103. https://doi.org/10.1016/j.labeco.2016.05.012

Coleman, J. (1961). The adolescent society. Free Press.

Coleman, J. (1988). Social Capital in the Creation of Human Capital. American Journal of Sociology 94, 95-120. https://www.jstor.org/stable/2780243 
PROTECT STUDENTS' EDUCATIONAL FUTURES THROUGH SOCIAL CAPITAL OPPORTUNITIES IN SPORTS AND NON-SPORT EXTRACURRICULAR ACTIVITIES

Dufur, M. J., Hoffmann, J. P., Braudt, D. B., Parcel, T. L., \& Spence, K. R. (2015). Examining the effects of family and school social capital on delinquent behavior. Deviant Behavior, 36(7), 511-526. doi: 10.1080/01639625.2014.944069

Dufur, M.J., Parce, R.L \& Troutman, K.P. (2013). Does capital at home matter more than capital at school? Social capital effects on academic achievement. Research in Social Stratification and Mobility, 31, 1-21. https://doi.org/10.1016/j.rssm.2012.08.002

Eide, E.R. and Nick Ronan (2001) Is participation in high school athletics an investment or consumption good?: Evidence from High School and beyond. Economic of Education Review 20(5), 431-442. https://doi.org/10.1016/S0272-7757(00)00033-9

Gorry, D. (2016). Heterogeneous effects of sports participation on education and labor market outcomes. Education Economics, 24(6), 622-638. doi: $\underline{10.1080 / 09645292.2016 .1143452}$

Haff, D.R.; Fitzpatrick, K.M., \& Floyd, H.H. (2010). Social capital and violence across racial and ethnic samples of adolescents. Journal of Health Disparities Research and Practice 4 (2), 1-15. https://digitalscholarship.unlv.edu/ihdrp/vol4/iss2/1

Hair, J.F.; Black, B.; Babin, B.; Anderson, R.E.; Tatham, R.L. (2012). Multivariate Data Analysis. 6th Ed. Prentice Hall.

Hanks, M.P. \& Eckland, B.K. (1976). Athletics and Social Participation in the Educational Attainment Process. Sociology of Education, 49(4), 271-294. doi: 10.2307/2112314

Harris, K.M., C.T. Halpern, E. Whitsel, J. Hussey, J. Tabor, P. Entzel, and J.R. Udry. 2009. The National Longitudinal Study of Adolescent to Adult Health: Research Design [WWW document]. URL: http://www.cpc.unc.edu/projects/addhealth/design.

Harris, Kathleen Mullan. 2009. The National Longitudinal Study of Adolescent to Adult Health (Add Health), Waves I \& II, 1994-1996; Wave III, 2001-2002; Wave IV, 2007-2009 [machine-readable data file and documentation]. Chapel Hill, NC: Carolina Population Center, University of North Carolina at Chapel Hill. doi: 10.3886/ICPSR27021.v9.

Hauser, W.J. \& Lueptow, L.B. (1978). Participation in athletics and academic achievement: a replication and extension. The Sociological Quarterly, 19 (2), 304-309. https://www.jstor.org/stable/4105639 
PROTECT STUDENTS' EDUCATIONAL FUTURES THROUGH SOCIAL CAPITAL OPPORTUNITIES IN SPORTS AND NON-SPORT EXTRACURRICULAR ACTIVITIES

Holland, A. \& Andre, T. (1987). Participation in extracurricular activities in secondary school: What is known, what needs to be known? Review of educational research 57 (4), 437466. doi: $10.2307 / 1170431$

Howell, F.M., Miracle, A.W., \& Rees, C.R. (1984). Do high school athletics pay? The effects of varsity participation socioeconomic attainment. Sociology of Sport Journal, 1, 15-25. http://doi.org/10.1123/ssj.1115

Hoyle, R.H. \& Panter, A.T. (1995). Writing About Structural Equation Models. In Structural Equation Modeling, eds. Rick H. Hoyle, 158-176, Sage.

Johnson, D.A. \& Acquaviva, J. (2012) Point/counterpoint: paying college athletes. The Sport Journal,15(1). https://thesportjournal.org/article/pointcounterpoint-paying-college-athletes/

Koebler, J. (2011, Sep, 2). High school participation increases for 22nd straight year. US News and World Report. https://news.yahoo.com/high-school-sports-participation-increases-22ndstraight-150842955.html

Kline, R. B. (2016). Principles and practice of structural equation modeling (4th ed). Guilford Press.

Kumar, Sunil (2015). Structure equation modeling basic assumptions and concepts: a novices guide. Asian Journal of Management Sciences, 3 (7), 25-28. https://www.researchgate.net/publication/328661630 Structure Equation Modeling Basic As sumptions and Concepts A Novices Guide

Lin, N. (1999) Social networks and status attainment. Annual Review of Sociology 25, 467-487. https://www.annualreviews.org/doi/abs/10.1146/annurev.soc.25.1.467

Mackin, R. S., \& Walther, C. S. (2012). Race, sport and social mobility: Horatio alger in short pants? International Review for the Sociology of Sport, 47(6), 670-689. https://doi.org/10.1177/1012690211429212

Lueptow, L.B. \& Kayser, B.D. (1973). Athletic involvement, academic achievement, and aspiration. Sociological Focus, 7, 24-36. https://www.jstor.org/stable/20830894

Mahatmya, D., \& Smith, A. (2017). Family and neighborhood influences on meeting college expectations in emerging adulthood. Emerging Adulthood, 5(3), 164-176. https://doi.org/10.1177/2167696816663833 
PROTECT STUDENTS' EDUCATIONAL FUTURES THROUGH SOCIAL CAPITAL OPPORTUNITIES IN SPORTS AND NON-SPORT EXTRACURRICULAR ACTIVITIES

Marsh, H.W. (1993). The Effects of Participation in Sport During the Last Two Years of High School. Sociology of Sport Journal, 10, 18-43. doi: 10.1123/ssj.10.1.18

Marsh, H.W. \& Kleitman, S. (2002). Extracurricular school activities: The good, the bad, and the nonlinear. Harvard Educational Review, 72(4), 464. doi: $10.17763 /$ haer.72.4.051388703v7v7736

McNeal, R.B. (1995). Extracurricular activities and high school dropouts. Sociology of Education, 68, 62-80. doi: 10.2307/2112764

Meyer, J. W., Ramirez, F. O., \& Soysal, Y. N. (1992). World expansion of mass education, 1870-1980. Sociology of Education, 65, 128-149. doi: 10.2307/2112679

Morrow, V. (1999). Conceptualizing social capital in relation to well-being of children and young people: a critical review. Sociological Review, 47, 744-765. doi: 10.1111/1467-954X.00194

Morrow, V. (2001). Young People's explanation and experiences of social exclusion: retrieving Bourdieu's concept of social capital. International Journal of Sociology and Social Policy 21 (4/5/6), 37-63. doi: 10.1108/01443330110789439

Nielsen, L. Vibeke Koushede, Mathilde Vinther-Larsen, Pernille Bendtsen, Annette Kjaer Ersbøll, Pernille Due, \& Bjørn E Holstein. (2015). Does school social capital modify socioeconomic inequality in mental health? A multi-level analysis in Danish schools. Social Science \& Medicine, 140, 35-43. https://doi.org/10.1016/i.socscimed.2015.07.002

O'Shaughnessy, L. (2012, September 20). 8 things you should know about sports scholarships. Money Watch. https://www.cbsnews.com/news/8-things-you-should-know-about-sportsscholarships/

Paccagnella, M., \& Sestito, P. (2014). School cheating and social capital. Education Economics, 22(3-4), 367-388. doi: 10.1080/09645292.2014.904277

Parcel, T. L., \& Bixby, M. S. (2016). The ties that bind: Social capital, families, and children's Well-Being. Child Development Perspectives, 10(2), 87-92. https://doi.org/10.1111/cdep.12165 
PROTECT STUDENTS' EDUCATIONAL FUTURES THROUGH SOCIAL CAPITAL OPPORTUNITIES IN SPORTS AND NON-SPORT EXTRACURRICULAR ACTIVITIES

Parcel, T.L., Dufur, M.J., \& Zito, R.C. (2010). Capital at home and at school: a review and synthesis. Journal of Marriage and Family 72, 828-846. https://doi.org/10.1111/j.1741$\underline{3737.2010 .00733 . x}$

Pfeifer, C. \& CorneliBen, T. (2010). The Impact of participation in sports on educational attainment-New evidence from Germany. Economics of Education Review, 29, 94-103. https://doi.org/10.1016/j.econedurev.2009.04.002

Pruter, R. (2013). The rise of American high school sports and the search for control, 1880-1930. Syracuse University Press.

Rees, D.I. \& Sabia, J.J. (2010). Sports participation and academic performance: Evidence from the National Longitudinal Study of Adolescent Health. Economics of Education Review, 29. https://doi.org/10.1016/i.econedurev.2010.04.008

Rothon, C., Goodwin, L., \& Stansfeld, S. (2012). Family social support, community “social capital" and adolescents' mental health and educational outcomes: A longitudinal study in England. Social Psychiatry and Psychiatric Epidemiology, 47(5), 697-709. doi: 10.1007/s00127$\underline{011-0391-7}$

Schaefer-McDaniel, N. J. (2004). Conceptualizing Social Capital among Young people: Toward a New Theory. Children, Youth, and Environment 14 (1), 140-150. https://www.jstor.org/stable/10.7721/chilyoutenvi.14.1.0153

Shifrer, D., Pearson, J., Muller, C., \& Wilkinson, L. (2015). College-Going Benefits of High School Sports Participation: Race and Gender Differences over Three Decades. Youth and Society, 47(3), 295-318. doi: 10.1177/0044118X12461656

Snellman, K., Silva, J. M., Frederick, C. B., \& Putnam, R. D. (2015). The engagement gap: social mobility and extracurricular participation among American youth. The ANNALS of the American Academy of Political and Social Science, 657(1), 194-207. https://doi.org/10.1177/0002716214548398

Spaaij, R., Farquharson, K., \& Marjoribanks, T. (2015). Sport and social inequalities. Sociology Compass, 9(5), 400-411. https://doi.org/10.1111/soc4.12254

Spady, E.E. (1971). Status, achievement, and motivation in the American high school. Social Review, 79, 379-403. https://doi.org/10.1086/442984 
PROTECT STUDENTS' EDUCATIONAL FUTURES THROUGH SOCIAL CAPITAL OPPORTUNITIES IN SPORTS AND NON-SPORT EXTRACURRICULAR ACTIVITIES

Stanton-Salazar, R. D. (2011). A social capital framework for the study of institutional agents and their role in the empowerment of low-status students and youth. Youth \& Society, 43(3), 1066-1109. https://doi.org/10.1177/0044118X10382877

Stanton-Salazar, R. D \& Dornbusch, S. M. (1995) Social capital and the reproduction of inequality: information networks among Mexican-origin high school students. Sociology of Education 68, 116-135. doi: 10.2307/2112778

Strohschein, L., \& Matthew, A. (2015). Adolescent problem behavior in Toronto, Canada. Sociological Inquiry, 85(1), 129-147. https://doi.org/10.1111/soin.12055

Thompson, B. (2000). Ten Commandments of Structural Equation Modeling. In Reading and Understanding More Multivariate Statistics, eds. Laurence Grimm and Paul Yarnold, 261-283. American Psychological Association.

Thorpe, K., Bell-Booth, R., Staton, S., \& Thompson, C. (2013). Bonding and bridging: Transition to school and social capital formation among a community of indigenous Australian children. Journal of Community Psychology, 41(7), 827-843. https://doi.org/10.1002/icop.21576

Weiss, H. E. (2012). The intergenerational transmission of social capital: A developmental approach to adolescent social capital formation. Sociological Inquiry, 82(2), 212-235. https://doi.org/10.1111/j.1475-682X.2012.00414.x

Widdop, P., Cutts, D., \& Jarvie, G. (2016). Omnivorousness in sport: The importance of social capital and networks. International Review for the Sociology of Sport, 51(5), 596-616. https://doi.org/10.1177/1012690214541101

Woolcock, M. (1998). Social capital and economic development: toward a theoretical synthesis and policy framework. Theory and Society 27, 151-208. https://doi.org/10.1023/A:1006884930135 
About the Author

Dr. Roxanne Noelle Long, Ph.D. (roxanne.long@unt.edu) is a Senior Lecturer in the Applied Arts and Sciences program at University of North Texas in Denton, Texas. The Applied Arts and Sciences program is a multi-disciplinary degree with a focus on non-traditional learners. She earned her Ph.D. in Sociology from the University of North Texas. With vast teaching experience, Roxanne emphasizes student-centered teaching and holistic education both in research focus and in practice. She has researched and presented on innovative classroom teaching techniques, reaching diversity of learners, and encompassing factors in educational attainment. 